\title{
Finding Spinel in All the Wrong Places**
}

\author{
By Thomas R. Hinklin, Jose Azurdia, Min Kim, Julian C. Marchal, Sameer Kumar, \\ and Richard M. Laine*
}

Spinel compounds are of continuing interest because they exhibit a wide range of novel and manipulable applications of value in electronic, magnetic, catalytic, photonic, and structural properties. ${ }^{[1-16]}$ Thus, the crystal structures, phase equilibria and composition ranges of materials that form both normal and inverse spinels have been studied extensively, frequently to optimize specific properties. Properties optimization drives continuing efforts to produce new materials, extend phase fields and improve homogeneity..$^{[1-18]}$ This in turn provides the impetus to develop new synthesis and processing approaches.

We recently demonstrated that liquid-feed flame spray pyrolysis, LF-FSP provides access to a new hexagonal phase in nano- $\mathrm{Y}_{3} \mathrm{Al}_{5} \mathrm{O}_{12}$ and a general route to nano- $\alpha-\mathrm{Al}_{2} \mathrm{O}_{3}$ (30$90 \mathrm{~nm}) .{ }^{[19,20]}$ We now find that LF-FSP offers a general route to common phase pure spinel nanopowders, $(\mathrm{MO})_{1-\mathrm{x}}\left(\mathrm{Al}_{2} \mathrm{O}_{3}\right)_{\mathrm{x}}$ $\mathrm{M}=\mathrm{Mg}, \mathrm{Ni}, \mathrm{Co}, \mathrm{Zn}$, and $(\mathrm{MgO})_{0.6}\left(\mathrm{Fe}_{2} \mathrm{O}_{3}\right)_{0.4}$, with compositions previously unknown thereby greatly extending their phase fields. ${ }^{[1,2,13-19,21]}$ Given their significant academic and commercial import, access to entirely new compositions in spinel phase materials could expand the horizons of spinel materials' properties greatly.

In LF-FSP, alcohol solutions of metalloorganics [e.g. $\mathrm{Al}\left(\mathrm{OCH}_{2} \mathrm{CH}_{2}\right)_{3} \mathrm{~N}$ (alumatrane) and $\left.\mathrm{Mg}(2,4 \text {-pentanedionato })_{2}\right]$ are aerosolized with $\mathrm{O}_{2}$ into a quartz chamber $(1.5 \mathrm{~m})$ and combusted ${ }^{[22]}$ at $1500^{\circ}-2000^{\circ} \mathrm{C}$. Quenching to $\approx 300^{\circ} \mathrm{C}$ in $\leq 30 \mu$ s over $\approx 1 \mathrm{~m}$ gives dispersible nanopowders often with novel phases as noted above ${ }^{[19,20]}$ and for example a one step synthesis of the difficult to produce $\mathrm{Na}^{+}$doped $\beta^{\prime \prime}$-alumina. ${ }^{[22]}$

In an effort to dope nano- $\alpha-\mathrm{Al}_{2} \mathrm{O}_{3}$ with $\mathrm{MgO}$ to prevent grain growth during sintering, ${ }^{[23,24]}$ LF-FSP was used to combinatorially produce $\mathrm{MgO}$ doped nano- $\delta-\mathrm{Al}_{2} \mathrm{O}_{3}$ as a prelude to a second pass through the LF-FSP system to produce Mg doped $\alpha-\mathrm{Al}_{2} \mathrm{O}_{3} \cdot{ }^{[24]}$ Figure 1 shows XRDs for LF-FSP generated $(\mathrm{MgO})_{\mathrm{x}}\left(\mathrm{Al}_{2} \mathrm{O}_{3}\right)_{1-\mathrm{x}}$ nanopowders where $\mathrm{x}=0-0.20$. Exact compositions were confirmed by XRF analyses. ${ }^{[22]}$

[*] Prof. R. M. Laine, T. R. Hinklin, J. Azurdia, M. Kim, J. C. Marchal, S. Kumar

Department of Materials Science and Engineering University of Michigan

Ann Arbor, MI 48109-2136 (USA)

E-mail: talsdad@umich.edu

[**] We thank the Air Force Office of Scientific Research for support of this work through Contract No. F49620-03-1-0389. Supporting Information is available online from Wiley InterScience or from the author.
As substantiated by numerous studies, ${ }^{[9-15,25-27]}$ the $\mathrm{MgO}-\mathrm{Al}_{2} \mathrm{O}_{3}$ phase diagram shows that stoichiometric spinel is stable to $\approx 2100{ }^{\circ} \mathrm{C}$ (see Supporting Information). It also indicates that in the alumina rich region, off-stoichiometric spinel phase forms at $63-83 \mathrm{~mol} \% \mathrm{Al}_{2} \mathrm{O}_{3}$ at $1500^{\circ}-1900^{\circ} \mathrm{C}$, but the stability zone contracts rapidly at higher temperatures. In contrast, LF-FSP processing provides a material that is $\geq 95 \%$ spinel phase at $90 \mathrm{~mol} \% \mathrm{Al}_{2} \mathrm{O}_{3}$ as determined by XRD and FTIR. ${ }^{[20-22]}$ Furthermore, at $\approx 94 \mathrm{~mol} \%$, XRD analysis indicates formation of a third phase together with a small amount of $\delta-\mathrm{Al}_{2} \mathrm{O}_{3}$ rather than $\alpha-\mathrm{Al}_{2} \mathrm{O}_{3}$, the expected second phase.

The third phase, observed at the $6.06 \mathrm{~mol} \% \mathrm{MgO}$ eutectic with an apparent formula of $\mathrm{MgAl}_{31} \mathrm{O}_{47.5}[]_{0.5}$, was reported previously to form near $93 \mathrm{~mol} \%$ alumina with a formula of $\mathrm{MgAl}_{26} \mathrm{O}_{40} \cdot{ }^{[26,27]} \mathrm{As}$ we recently reported, for $(\mathrm{MgO})_{\mathrm{x}}\left(\mathrm{Al}_{2} \mathrm{O}_{3}\right)_{1-\mathrm{x}}$, one can track the changes in specific phases observed through changes in lattice parameters and FTIR absorption band positions as a function of composition.

These results combined with studies on nickel aluminates, $(\mathrm{NiO})_{\mathrm{x}}\left(\mathrm{Al}_{2} \mathrm{O}_{3}\right)_{1-\mathrm{x}},{ }^{[28]}$ prompted efforts to explore the general utility of LF-FSP to produce hitherto unknown spinel compositions in different nano-alumina spinels. Figure 2 provides XRDs for selected compositions of $(\mathrm{MO})_{\mathrm{x}}\left(\mathrm{Al}_{2} \mathrm{O}_{3}\right)_{1-\mathrm{x}}$ for $\mathrm{M}=\mathrm{Ni}, \mathrm{Co}, \mathrm{Mg}$ and $\mathrm{Zn}$ which are all stable to $1150^{\circ} \mathrm{C}$.

All of these nanopowders have typical average particle sizes of $20-40 \mathrm{~nm}$ (see Figure 3 examples) and corresponding surface areas of $50-70 \mathrm{~m}^{2} \mathrm{~g}^{-1}$. In some instances, as in the nickel system, ${ }^{[28]}$ the materials are mostly the inverse spinel.

The reported $(\mathrm{NiO})_{\mathrm{x}}\left(\mathrm{Al}_{2} \mathrm{O}_{3}\right)_{1-\mathrm{x}}$ phase diagram shows a spinel phase field in the alumina rich region that extends from $\mathrm{x}=0.50$ to 0.60 at $1500^{\circ} \mathrm{C}$ but broadens to $\approx 0.68$ at temperatures near $2000^{\circ} \mathrm{C}^{[29]}$ Thus, our observation of a pure spinel phase at $\mathrm{x}=0.78$ greatly extends this phase field. The resulting spinel is very stable, resisting transformation to the phase diagram composition even on heating for $10 \mathrm{~h}$ at $1150^{\circ} \mathrm{C}$, Figure 2.

Similar observations are made for the $(\mathrm{CoO})_{\mathrm{x}}\left(\mathrm{Al}_{2} \mathrm{O}_{3}\right)_{1-\mathrm{x}}$ system, where at $1500^{\circ} \mathrm{C}$ the published phase diagram in the alumina rich region extends to $45 \mathrm{~mol} \%(\mathrm{x}=0.45)$ but expands to $78 \mathrm{~mol} \%$ near $1950{ }^{\circ} \mathrm{C} \cdot{ }^{[31,32]}$ We observe a pure spinel phase at $79 \mathrm{~mol} \%$ and mostly spinel at $90 \mathrm{~mol} \%$ with some $\delta-\mathrm{Al}_{2} \mathrm{O}_{3}$. Here we appear to be equivalent to the thermodynamic materials. But our materials exhibit a shift in the powder pattern of $0.3-0.4^{\circ} 2 \theta$ with the secondary phase being $\delta$ - rather 


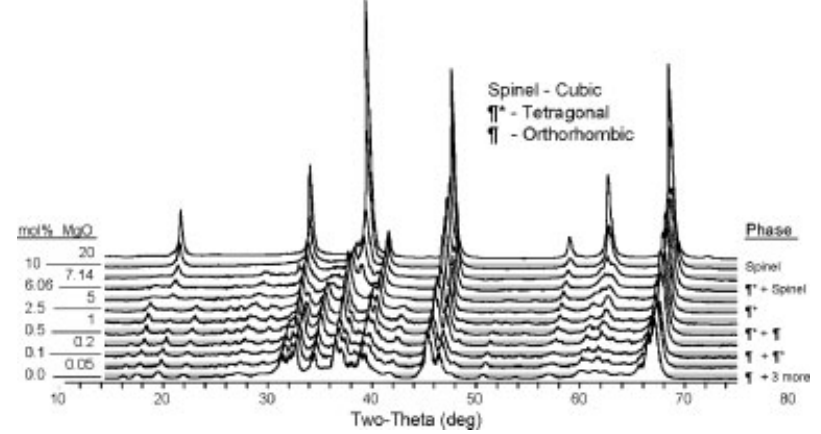

Figure 1. $\mathrm{XRDs}$ for $(\mathrm{MgO})_{\mathrm{x}}\left(\mathrm{Al}_{2} \mathrm{O}_{3}\right)_{1-\mathrm{x}}$ for $\mathrm{x}=0-20 \mathrm{~mol} \%, \mathrm{MgO}$ content determined by XRF [25].

than $\alpha-\mathrm{Al}_{2} \mathrm{O}_{3}$. We assume the shift in ${ }^{\circ} 2 \theta$ is due in part to some inverse spinel forming and also substitution of the much smaller $\mathrm{Al}^{3+}$ ion for $\mathrm{Co}^{2+}$ in tetragonal sites. ${ }^{[30,31]}$

For $(\mathrm{ZnO})_{\mathrm{x}}\left(\mathrm{Al}_{2} \mathrm{O}_{3}\right)_{1-\mathrm{x}}$, the published phase diagram ${ }^{[32]}$ shows that in the $\mathrm{Al}_{2} \mathrm{O}_{3}$ rich region at $57 \mathrm{~mol} \% \mathrm{Al}_{2} \mathrm{O}_{3}$, the spinel phase is stable only in a very narrow window from 1700 to $1800^{\circ} \mathrm{C}$. Below $1700^{\circ} \mathrm{C}$ a mixture of $\alpha-\mathrm{Al}_{2} \mathrm{O}_{3}$ and spinel phase are observed. However, in the LF-FSP materials, we observe phase pure spinel at $(\mathrm{ZnO})_{0.33}\left(\mathrm{Al}_{2} \mathrm{O}_{3}\right)_{0.67}$ perhaps suggesting that the formation temperatures of our powders are $\geq 1700^{\circ} \mathrm{C}$ and that we trap the phase pure spinel by rapid quenching. Note that according to the phase diagram, ${ }^{[32]} \mathrm{a}$ liquid spinel/solid $\alpha-\mathrm{Al}_{2} \mathrm{O}_{3}$ mixture forms above $1800^{\circ} \mathrm{C}$. Given the size of our particles and the fact that nano particles are likely to be liquid well below the bulk melting temperature, we suspect that in our system the as-produced powders form from liquid droplets produced in the flame.

On heating to temperatures of $1400-1500^{\circ} \mathrm{C}$, these materials transform to the expected phase compositions [spinel $/ \alpha-\mathrm{Al}_{2} \mathrm{O}_{3}$ a)

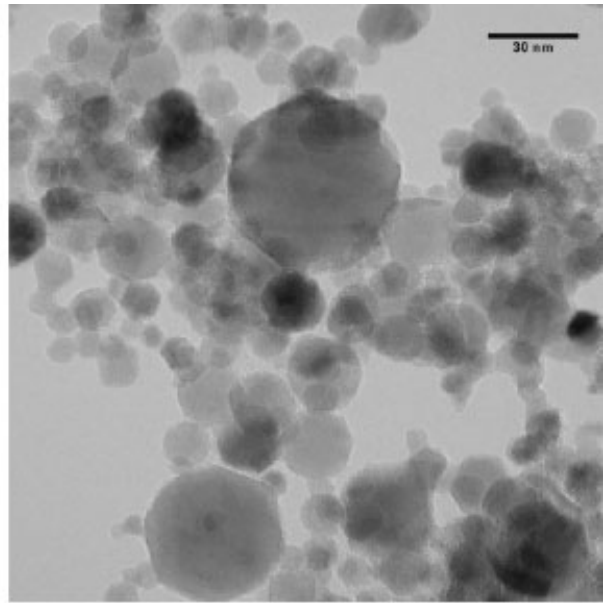

b)

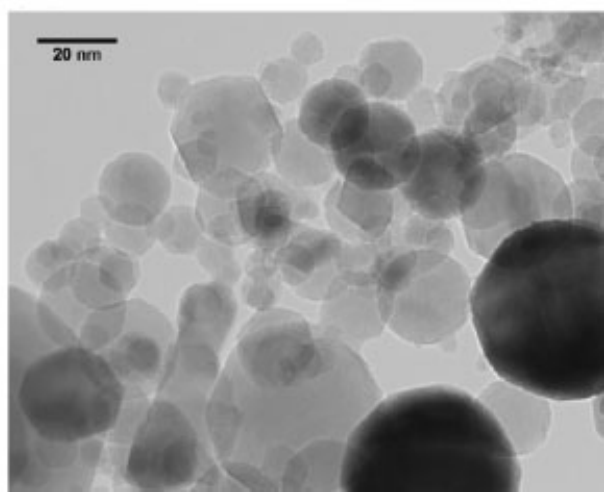

Figure 3. TEMs of (a) $(\mathrm{NiO})_{0.22}\left(\mathrm{Al}_{2} \mathrm{O}_{3}\right)_{0.78}$ and (b) $(\mathrm{CoO})_{0.08}\left(\mathrm{Al}_{2} \mathrm{O}_{3}\right)_{0.92}$.

$\left.\left(\alpha-\mathrm{Fe}_{2} \mathrm{O}_{3}\right)\right]$ as shown in Figure 2, confirming the true compositions of the LF-FSP produced nanopowders. However, they are all stable at $1150{ }^{\circ} \mathrm{C}$ for prolonged periods pointing to their potential to offer unique properties at moderate temperatures, for example as catalysts.

In all of the Figure 2 as-produced materials, the alumina rich region of the phase diagram indicates that $\alpha-\mathrm{Al}_{2} \mathrm{O}_{3}$ is the expected second phase for all temperatures. Yet, we observe only $\delta-\mathrm{Al}_{2} \mathrm{O}_{3}$ presumably because in all cases we are producing kinetic products. An alternate explanation is that $\delta-\mathrm{Al}_{2} \mathrm{O}_{3}$ forms as a separate nanopowder product during LF-FSP rather than in an intimate phase separated mixture. However for the phase pure materials, no evidence of a second $\delta-\mathrm{Al}_{2} \mathrm{O}_{3}$ phase is observed belying this explanation.

To better demonstrate generality, we also prepared $(\mathrm{MgO})_{\mathrm{x}}\left(\mathrm{Fe}_{2} \mathrm{O}_{3}\right)_{1-\mathrm{x}}$ materials using the same processing conditions as for the $(\mathrm{MO})_{\mathrm{x}}\left(\mathrm{Al}_{2} \mathrm{O}_{3}\right)_{1-\mathrm{x}}$ systems discussed above. Iron propionate, $\mathrm{Fe}\left(\mathrm{O}_{2} \mathrm{CCH}_{2} \mathrm{CH}_{3}\right)_{3}$, and $\mathrm{Mg}(2,4 \text {-pentanedionato })_{2}$ were used to make various $(\mathrm{MgO})_{\mathrm{x}}\left(\mathrm{Fe}_{2} \mathrm{O}_{3}\right)_{1-\mathrm{x}}$ compositions in the
Figure 2. XRD powder patterns for $(\mathrm{MO})_{x}\left(\mathrm{Al}_{2} \mathrm{O}_{3}\right)_{1-x}$ for $x$ as shown and $(\mathrm{MgO})_{0.33}\left(\mathrm{Fe}_{2} \mathrm{O}_{3}\right)_{0.67}$ for powders heated to $1150^{\circ} \mathrm{C}\left(10^{\circ} \mathrm{C} / \mathrm{min} /\right.$ air $)$ or $1500^{\circ} \mathrm{C} / 12 \mathrm{~h}$. $*=\alpha-\mathrm{Al}_{2} \mathrm{O}_{3}, \diamond=\alpha-\mathrm{Fe}_{2} \mathrm{O}_{3}$ $\left(1400^{\circ}\right)$. 
range $\mathrm{x}=29-63 \mathrm{MgO}$ as measured by $\mathrm{XRF}{ }^{[33]}$ These nanopowders have typical average particle sizes of $<40 \mathrm{~nm}$ and corresponding surface areas of $\approx 50 \mathrm{~m}^{2} \mathrm{~g}^{-1}$ as confirmed by SEM and BET. The materials were analyzed by XRD, and determined to all be single-phase magnesioferrite spinel at compositions $\leq \mathrm{x}=70$.

According to the published phase diagram for the $(\mathrm{MgO})_{\mathrm{x}}$ $\left(\mathrm{Fe}_{2} \mathrm{O}_{3}\right)_{1-\mathrm{x}}$ system, ${ }^{[34]}$ these materials should exist as phase separated spinel + periclase $(\mathrm{MgO})$ at $\mathrm{x}>0.5$, and spinel + hematite $\left(\mathrm{Fe}_{3} \mathrm{O}_{4}\right)$ for $\mathrm{x} \leq 0.5$. Similar to the $(\mathrm{MO})_{\mathrm{x}}\left(\mathrm{Al}_{2} \mathrm{O}_{3}\right)_{1-\mathrm{x}}$ systems, we observe single-phase spinel for compositions as much as $\approx 15 \mathrm{~mol} \%$ outside the thermodynamically determined phase field.

In summary, it is clear that a combination of very homogeneous mixing of ionic species in the gas phase at very high temperatures followed by a very rapid quench provides a general means of producing sets of spinel nanomaterials that were hitherto impossible or very difficult to obtain previously. Furthermore, the $(\mathrm{MgO})_{\mathrm{x}}\left(\mathrm{Fe}_{2} \mathrm{O}_{3}\right)_{1-\mathrm{x}}$ powders, which are superparamagnetic, suggest that our approach to novel materials is not limited to aluminates. Because spinel phase materials are of such significant academic and commercial import, the process and the materials described here show considerable portent to develop entirely new materials some of which are certain to have sets of properties hitherto unknown. Thus, the horizons of spinel materials have been expanded greatly.

\section{Experimental}

Materials: All precursors were prepared using methods described elsewhere. [21, 22, 28, 33]

Nanopowder Processing: Solutions of $2-5 \mathrm{wt} \%$ ceramic as precursors in EtOH are aerosolized with oxygen at rates of 100-200 $\mathrm{ml} \mathrm{min}^{-1}$, ignited generating turbulent flames in a quartz reactor at temperatures $\leq 1800^{\circ} \mathrm{C}$ and thereafter quenched $1.5 \mathrm{~m}$ later to temperatures of $300-400^{\circ} \mathrm{C}$ and collected in electrostatic precipitators. [20-22, 28, 30] Powder Characterization: Powders were characterized by BET, FTIR, XRD and SEM, TEM and TGA/DTA using methods described previously. [20-22, 28, 30]

Received: August 22, 2007

Revised: October 11, 2007

[1] H. S. C. O'Neill, A. Navrotsky, Am. Mineral. 1983, 68, 181.

[2] K. E. Sickafus, J. M. Wills, N. W. Grimes, J. Am. Ceram. Soc. 1999, 82, 3279.
[3] M. Han, C. R. Vestal, Z. J. Zhang, J. Phys. Chem. B 2004, 108, 583.

[4] D. R. Parker, M. A. Green, S. T. Bramwell, A. S. Wills, J. S. Gaarner, D. A. Neumann, J. Am. Chem. Soc. 2004, 126, 2710.

[5] D. R. Clarke, J. Am. Ceram. Soc. 1999, 82, 485.

[6] V. T. Gritsyna, I. V. Afanasyev-Charkin, V. A. Kobyakov, K. E. Sickafus, J. Am. Ceram. Soc. 1999, 82, 3365.

[7] C. O. Arean, M. P. Mentruit, E. E. Platero, F. X. Llabres i Xamena, J. B. Parra, Mater. Lett. 1999, 39, 22.

[8] C. O. Arean, B. S. Sintes, G. T. Palomino, C. M. Carbonell, E. E. Platero, J. B. P. Soto, Micropor. Mater. 1997, 8, 187.

[9] P. J. Patel, G. A. Gilde, P. G. Dehmer, J. W. McCauley, in: Inorganic Optical Materials II, Vol. 4102, (Eds: A. J. Marker, III E. G. Arthurs), SPIE, 2000, pp. 1-14.

[10] J. S. Yoo, A. A. Bhattachariyya, C. A. Radlowski, Ind. Eng. Chem. Res. 1991, 30, 1444.

[11] H. Kagata, R. Saito, H. Kastumura, J. Electroceram. 2004, 13, 277.

[12] P. C. Panda, R. Raj, J. Am. Ceram. Soc. 1986, 69, 363.

[13] T. R. Hinklin, R. M. Laine, Chem. Mater. 2008, 20, 553.

[14] M. F. Zawrah, Mater. Sci. Eng. A. 2004, 382, 362.

[15] A. Navrotsky, B. A. Wechsler, K. Geisinger, F. Seifert, J. Am. Ceram. Soc. 1986, 69, 418.

[16] S. Bhaduri, S. B. Bhaduri, Ceram. Internat. 2002, 28, 153.

[17] N. Yang, L. Chang, Mater. Lett. 1992, 15, 84.

[18] Several $\mathrm{MgO} \cdot \mathrm{Al}_{2} \mathrm{O}_{3}$ spinel precursors have been synthesized, characterized and described in the literature. ${ }^{[19-22]}$.

[19] K. B. Pflanz, R. Riedel, H. Chmiel, Adv. Mater. 1992, 4, 662.

[20] M. Veith, A. Altherr, H. Wolfanger, Chem. Vap. Deposition 1999, 5 , 87.

[21] R. M. Laine, J. Marchal, H. J. Sun, X. Q. Pan, Adv. Mater. 2005, 17, 830.

[22] C. R. Bickmore, K. F. Waldner, D. R. Treadwell, R. M. Laine, J. Am. Ceram. Soc. 1996, 79, 1419.

[23] A. C. Sutorik, S. S. Neo, T. Hinklin, R. Baranwal, D. R. Treadwell, R. Narayanan, R. M. Laine, J. Am. Ceram. Soc. 1998, 81, 1477.

[24] A. Krell, P. Blank, H. Ma, T. Hutzler, M. P. B. van Bruggen, R. Apetz, J. Am. Ceram. Soc. 2003, 86, 12.

[25] R. Apetz, M. P. B. van Bruggen, J. Am. Ceram. Soc. 2003, 86, 480.

[26] B. Hallstedt, J. Am. Ceram. Soc. 1992, 75, 1497 and references therein

[27] A. Mangin, H. Forestier, C.R. hebd. Séances Acad. Sci. 1956, 242, 1893.

[28] H. Jagodzinski, Zeitschrift für Kristallographie 1957, 109, S. 388.

[29] J. A. Azurdia, J. C. Marchal, P. Shea, H. Sun, X. Q. Pan, R. M. Laine, Chem. Mater. 2006, 18, 731.

[30] B. Phillips, J. J. Hutta, I. Warshaw, J. Am. Ceram. Soc. 1963, 46, 581.

[31] J. Azurdia, J. C. Marchal, R. M. Laine, J. Am. Ceram. Soc. 2006, 89, 2749.

[32] T. Mori, Nippon. Seram. Kyo. Gak 1982, 90, 100.

[33] R. Hansson, P. C. Hayes, E. Jak, Metall. Mater. Trans. B 2004, 35B, 633.

[34] S. Kumar, R. M. Laine, unpublished.

[35] J. C. Willshee, J. White, Trans. Br. Ceram. Soc. 1967, 54, 333. 